\title{
Nutrient deposition enhances post-fire survival in non-N-fixing savanna tree seedlings
}

\author{
Varun Varma ${ }^{1,2 *} \&$ Mahesh Sankaran ${ }^{1,3}$ \\ ${ }^{1}$ Ecology and Evolution Group, National Centre of Biological Sciences \\ (NCBS), Tata Institute of Fundamental Research (TIFR), GKVK campus, \\ Bellary Road, Bangalore -560 065, Karnataka, India. \\ ${ }^{2}$ Department of Biosciences, University of Exeter, Exeter EX4 4QD, UK. \\ ${ }^{3}$ School of Biology, University of Leeds, Leeds, LS2 9JT, UK. \\ * Corresponding author - Varun Varma - email: varunvarma17@gmail.com
}

\begin{abstract}
Nutrient deposition can modify plant growth rates and potentially alter the susceptibility of plants to disturbance events, while also influencing properties of disturbance regimes. In mixed tree-grass ecosystems, such as savannas and tropical dry forests, tree seedling growth rates strongly influence the ability of seedlings to survive fire (i.e. post-fire seedling survival), and hence, vegetation structure and tree community composition. However the effects of nutrient deposition on the susceptibility of recruiting trees to fire are poorly quantified. In a field experiment, seedlings of multiple $\mathrm{N}$-fixing and non-N-fixing tropical dry forest tree species were exposed to nitrogen $(\mathrm{N})$ and phosphorus $(\mathrm{P})$ fertilisation, and fire. We quantified nutrientmediated changes in a) mean seedling growth rates; b) growth rates of the fastest growing individuals and c) post-fire seedling survival. $\mathrm{N}$-fixers had substantially higher baseline postfire seedling survival, that was unaffected by nutrient addition. Fertilisation, especially with $\mathrm{N}$, increased post-fire survival probabilities in non-N-fixers by increasing the growth rates of the fastest growing individuals. These results suggest that fertilisation can lead to an increase in the relative abundance of non-N-fixers in the resprout community, and thereby, alter the community composition of tropical savanna and dry forest tree communities in the long-term.
\end{abstract}

Keywords: nutrient deposition, nitrogen, phosphorus, savannas, tropical dry forests, plant functional groups, tree seedlings, legumes, non-legumes, fire.

\section{Introduction}

Increased atmospheric deposition of nitrogen $(\mathrm{N})$ and phosphorus $(\mathrm{P})$ as a consequence of human activities is an important global change driver (Vitousek 1994; Vitousek et al. 1997; Sala et al. 2000; Falkowski et al. 2000; Galloway et al. 2004, 2008; Phoenix et al. 2006, 2012; Dentener et al. 2006; Mahowald et al. 2008; Du and Liu 2014; Vet et al. 2014) that has been shown to modify vegetation communities in a number of ecosystems (Elser et al. 2007; Xia and Wan 2008; Bobbink et al. 2010). Numerous studies have demonstrated that increased availability of these essential plant nutrients can differentially affect plant growth amongst members of a community, bringing about compositional changes in vegetation assemblages (Huante et al. 1995a, b; Zavaleta et al. 2003; Khurana and Singh 2004; Stevens et al. 2004, 2006, 2010; Wassen et al. 2005; Elser et al. 2007; Clark and Tilman 2008; Xia and Wan 2008; Tripathi and Raghubanshi 2014; Verma et al. 2014; Powers et al. 2015). In addition, increased nutrient availability can also indirectly modify plant communities by affecting properties of local disturbance regimes - which play a ubiquitous role 
in shaping ecosystems across the globe - and by modifying the susceptibility of plant species to disturbance events (Heil and Diemont 1983; Bobbink and Lamers 2002; Strengbom et al. 2002; Bobbink et al. 2010; Barbosa et al. 2014b; Varma et al. 2018). To assess the net effect of nutrient deposition on vegetation communities, we need to therefore consider both direct nutrient-mediated effects on plant growth, as well as indirect effects that arise through alterations in disturbance characteristics and the differential susceptibility of plant species to these altered disturbance regimes.

Mixed tree-grass ecosystems, such as savannas and seasonally dry tropical forests with grassy understories, are globally important biomes (Murphy and Lugo 1986; Field et al. 1998; Powers and Tiffin 2010; McShea et al. 2011), covering approximately $20 \%$ of the Earth's terrestrial surface (Scholes and Archer 1997). However, as with tropical ecosystems in general (Matson et al. 1999; Siddique et al. 2010; Bobbink et al. 2010; Lu et al. 2010), the effects of atmospheric nutrient deposition on the dynamics of mixed tree-grass ecosystems are relatively poorly investigated (Powers et al. 2015). Vegetation in these systems is characterised by a spatially discontinuous tree canopy, interspersed within a continuous layer of $\mathrm{C}_{4}$ grasses (Scholes and Archer 1997; Bond et al. 2003a; House et al. 2003; Bond 2008; Lehmann et al. 2009b; Edwards et al. 2010; Bond and Parr 2010; Ratnam et al. 2011). The availability of resources such as water and nutrients, as well as disturbances, such as fire and herbivory, strongly influence the extent of woody cover and tree species diversity in these communities (Sankaran et al. 2004, 2005, 2008; Lehmann et al. 2009a, 2014; Staver et al. 2009; Dantas et al. 2015). They are also amongst the most frequently burned biomes in the world (Dwyer et al. 1998, 2000; Barbosa et al. 1999; Tansey et al. 2004; Bond et al. 2005), and in the wetter regions of these biomes (e.g. in Africa, where annual precipitation $>650 \mathrm{~mm}$ ), grass-fuelled fires are the single most important constraint to the recruitment of trees into the adult canopy layer (Higgins et al. 2000; Sankaran et al. 2005; Bond 2008).

In the long-term, nutrient deposition has the potential to alter tree canopy cover in mixed tree-grass ecosystems, both directly, through their effects on tree seedling growth, as well as indirectly via effects on grass growth, which in turn can modify the strength of tree-grass competition and the nature of fire regimes. Tree seedlings in general demonstrate enhanced growth with nutrient availability (Huante et al. 1995a; Khurana and Singh 2004; Vadigi and Ward 2013; Varma et al. 2018) and may therefore be expected to show increased post-fire survival because larger seedlings survive fires better (Trollope 1984; Gignoux et al. 1997; Hoffmann and Solbrig 2003; Bond 2008; Lawes et al. 2011; Wakeling et al. 2011). However, nutrientmediated increases in seedling growth are also typically associated with reduced relative investment in root biomass, as well as root carbohydrates (Tilman 1988; Khurana and Singh 2004; Knox and Clarke 2005; Hermans et al. 2006; Wang et al. 2015; Varma et al. 2018), which in turn could negatively influence post-fire seedling survival and resprouting ability (Hoffmann et al. 2000; Bell 2001; Bond et al. 2003b; Lamont and Wiens 2003; Vesk and Westoby 2004; Clarke and Knox 2009; Wigley et al. 2009; Clarke et al. 2013). In addition, increases in grass productivity with fertilisation (Fynn and O'Connor 2005; Lee et al. 2010) has the potential to negatively affect tree seedling growth and survival, both as a result of increased grass competition (Higgins et al. 2000; Kraaij and Ward 2006; Cramer et al. 2010; Kambatuku et al. 2012; Cramer and Bond 2013; Vadigi and Ward 2013, 2014), as well as more intense and frequent grass-fuelled fires (Williams et al. 1999; Higgins et al. 2000; Ryan and Williams 2011; Hoffmann et al. 2012).

In addition to influencing structure, $\mathrm{N}$ and $\mathrm{P}$ deposition can also potentially lead to changes in the functional composition of tree communities in mixed tree-grass ecosystems if they have differential effects on the growth and survival of dominant tree functional types in the system, i.e. $\mathrm{N}$-fixers and non-N-fixers. N-fixers and non-N-fixers have contrasting nutrient demands and acquisition strategies (Vitousek et al. 2002, 2013; Pearson and Vitousek 2002) which can result in differing growth responses of these functional groups to nutrient enrichment (Khurana and Singh 2004; Cramer et al. 2007; Barbosa et al. 2014a; Tripathi and Raghubanshi 2014; Varma et al. 2018). Furthermore, differences between functional groups in their ability to withstand grass competition (Cramer et al. 2007, 2010), and in biomass allocation patterns to above- versus 
below-ground organs and root carbohydrate reserves (Khurana and Singh 2004; Tripathi and Raghubanshi 2014; Varma et al. 2018) can result in differing post-fire resprouting and survival with $\mathrm{N}$ and $\mathrm{P}$ fertilisation.

Ultimately, the long-term effects of nutrient deposition on the structure and composition of mixed tree-grass systems will depend on the relative strengths of these direct and indirect nutrient-mediated effects. Although a few previous studies have investigated how nutrient availability and fire influence the growth and survival of N-fixing and non-N-fixing species (Kraaij and Ward 2006; Higgins et al. 2007; Cramer et al. 2007, 2010, 2012; Kambatuku et al. 2012; Vadigi and Ward 2012, 2013, 2014; Cramer and Bond 2013; Barbosa et al. 2014a, b), particularly in African savannas, our understanding of the individual and interactive effects of nutrients and fire on tree demography in these systems remains incomplete. Few studies have looked at the effects of $\mathrm{N}$ and $\mathrm{P}$ separately, and fewer still, in the context of Asian savannas.

Here, we report results from a field experiment that investigated the effects of $\mathrm{N}$ and $\mathrm{P}$ fertilisation and fire on seedling growth and survival of multiple $\mathrm{N}$-fixing and non-N-fixing tropical savanna and dry forest tree species in India. The main aim of this experiment was to determine the extent to which projected increases in anthropogenic $\mathrm{N}$ and $\mathrm{P}$ deposition are likely to affect tree seedling establishment in tropical savannas and dry forests of the Indian subcontinent, and thereby, potentially alter tree demography and functional composition of the region. More specifically, our objectives were to quantify the effects of $\mathrm{N}$ and $\mathrm{P}$ fertilisation on 1) seedling growth rates, including both mean growth rates as well as growth rates of the fastest growing individuals (Wakeling et al. 2011) of $\mathrm{N}$-fixing and non-N-fixing species, in the presence of grass competition, 2) grass biomass production, and thus, fuel load accumulation, and 3) post-fire seedling survival of $\mathrm{N}$-fixing and non-N-fixing species.

\section{Methods}

The experiment was conducted on 0.5 ha of abandoned farm land in the village of Hosur, located in Mysore district of the southern Indian state of Karnataka. The region receives approximately $800 \mathrm{~mm}$ of rainfall annually, primarily from the south-west monsoon between June and October (Indian Meteorological Department - http://www.imd.gov.in). This is followed by a dry season from December to April. Fires are typically observed between February and April when average day-time temperatures range from $31^{\circ} \mathrm{C}$ to $35^{\circ} \mathrm{C}$.

Between August and October, 2012, prior to the start of the experiment, the top $30 \mathrm{~cm}$ of soil was homogenised with two rounds of ploughing, and the experimental area was fenced to exclude livestock and human disturbance. Forty eight experimental plots were subsequently established ( $8 \mathrm{~m} \mathrm{X} 8 \mathrm{~m}$ ) by placing nonleaching plastic lining up to a depth of $0.5 \mathrm{~m}$ around them to prevent the movement of added nutrients between plots. Grasses were allowed to naturally regenerate in the experimental plots.

Eight commonly occurring tropical dry forest tree species (Puyravaud et al. 1994; Sagar and Singh 2004; Kumar and Shahabuddin 2005; Kodandapani et al. 2008) were selected for the experiment which included four N-fixers (Acacia ferruginea DC., Albizia amara (Roxb.) B.Biovin., Albizia lebbeck (L.) Benth. and Dalbergia latifolia (Roxb.)) and four non-N-fixers (Lagerstroemia speciosa (L.), Sapindus emarginatus Vahl., Terminalia arjuna (Roxb. ex DC.) and Ziziphus jujuba Mill.). All N-fixers used in this experiment have previously been shown to nodulate (Germplasm Resource Information Network - http://www.arsgrin.gov/; also see Varma et al. 2018). Seedlings of the eight species were obtained from the Foundation for Revitalisation of Local Health Traditions (FRLHT), Bangalore and transported to the field site six weeks after germination. In November 2012, after a two-week acclimation period, 68 seedlings across all eight species were planted into each treatment plot. Plants were placed at random within a grid with a minimum spacing of $80 \mathrm{~cm}$ between adjacent plants. The number of individuals per species varied within plots $(A$. ferruginea $=10, A$. amara $=6$, A. lebbeck $=5, D$. latifolia $=10, L$. speciosa $=10, S$. emarginatus $=8, T$. arjuna $=9, Z$. jujuba $=10$ ). However, each plot contained identical numbers of individuals of each species at 
the start of the experiment. To aid establishment and reduce seedling mortality, additional water was supplied to seedlings manually and using a sprinkler system from November 2012 to June 2013.

Twelve treatment plots were randomly assigned to one of four nutrient treatments - control (no added nutrients $), \mathrm{N}+\left(2 \mathrm{~g} \mathrm{~N} \cdot \mathrm{m}^{-2} \cdot \mathrm{y}^{-1}\right), \mathrm{P}+\left(0.2 \mathrm{~g} \mathrm{P} \cdot \mathrm{m}^{-2} \cdot \mathrm{y}^{-1}\right)$ and $\mathrm{NP}+\left(2 \mathrm{~g} \mathrm{~N} \cdot \mathrm{m}^{-2} \cdot \mathrm{y}^{-1}\right.$ and $\left.0.2 \mathrm{~g} \mathrm{P} \cdot \mathrm{m}^{-2} \cdot \mathrm{y}^{-1}\right)$. The N and P addition levels used represent conservative estimates of atmospheric $\mathrm{N}$ (Dentener et al. 2006) and $\mathrm{P}$ (Mahowald et al. 2008) deposition expected by 2030 over southern India. Nutrients were evenly applied to each treatment plot as solutions of urea and single superphosphate for $\mathrm{N}$ and $\mathrm{P}$, respectively. Nutrient additions were carried out in two applications in November-December, 2012, three applications in JulyAugust, 2013 and three applications in July-August, 2014. Seedling height (using a tape measure) and basal stem diameter (measured $2 \mathrm{~cm}$ above the ground using a vernier calliper) were measured for each individual one-week after transplant in November $2012\left(\mathrm{H}_{1}\right.$ and $\mathrm{D}_{1}$ hereafter for height and stem diameter, respectively) and again 15 months later in February $2014\left(\mathrm{H}_{2}\right.$ and $\mathrm{D}_{2}$ hereafter for height and stem diameter, respectively). Seedling relative growth rates for stem height and diameter were calculated as $\left(\mathrm{H}_{2}-\mathrm{H}_{1}\right) / \mathrm{H}_{1}$ and $\left(\mathrm{D}_{2}-\mathrm{D}_{1}\right) / \mathrm{D}_{1}$, respectively. Additionally, in February 2014, herbaceous biomass from three $10 \mathrm{~cm}$ x $20 \mathrm{~cm}$ quadrats (separated into grass and forb biomass) was harvested from each of the 48 experimental plots to quantify fuel load.

Coinciding with the peak of the dry season in February-March 2014, six plots from each nutrient treatment level (total of 24 plots) were selected at random for the fire treatment. Prior to burning, all above-ground biomass in plots (excluding the transplanted seedlings) was clipped and placed back within the plots to facilitate even drying of the fuel layer and prevent fires from spreading to adjacent plots. Flame heights during burning were observed to be well in excess of the heights of most seedlings, suggesting that pre-burn clipping of the grass layer was unlikely to have significantly modified the effect of fire on seedlings. Seedling survival was quantified at the end of the wet season following burning (September 2014). Seedlings that showed no live above-ground biomass, i.e. had not resprouted, were scored as dead.

\section{$\underline{\text { Data analysis }}$}

The effects of $\mathrm{N}$ and $\mathrm{P}$ addition on pre-burn relative growth rates of tree seedlings were evaluated using linear mixed effects models, with nutrient treatment and functional group included as fixed effects. Species identity was used a random factor within these models, as the focus of the analysis was to detect functional group level generalisations, while accounting for intrinsic species-specific differences in relative growth rates. In addition, data from plants in the control treatment were used to quantify baseline differences in the growth rates of $\mathrm{N}$-fixers and non-N-fixers. Growth rates for seedlings in the control treatment were modelled as a function of initial size and plant functional group, with species identity included as a random factor.

A bootstrapping method was used to quantify the effect of nutrients on growth rates of the fastest growing seedlings. Growth rates of all individuals were resampled with replacement (100 iterations) for each speciestreatment combination separately. At each iteration, the log response ratio (LRR) between the 75th percentile of growth rates in the nutrient treatment and that of the control treatment were calculated. Changes in the growth rates of the fastest growing individuals with fertilisation were represented by the mean LRR and associated $95 \%$ confidence intervals (CIs), i.e. the LRR represents the change in $75^{\text {th }}$ percentile growth rate of a species with fertilisation and the $95 \%$ CIs around the LRR captures the variation around the response. In addition, mean 75 th percentile growth rates and $95 \%$ CIs in the control treatment for each species were also reported. The effects of nutrient treatments on grass, forb and total herbaceous biomass were analysed using separate linear mixed effects models, where plot identity was used as a random factor.

The effect of $\mathrm{N}$ and $\mathrm{P}$ fertilisation on seedling mortality following fire was analysed using a generalised linear mixed effects model with a binomial error distribution. The analysis allowed for a three-way interaction between nutrient treatment, fire treatment (unburned and burned) and plant functional group. 
Species identity was included as a random factor. Additionally, we assessed the effect of plant size $\left(\mathrm{H}_{2}\right.$ and $\mathrm{D}_{2}$ - measured before the application of fire) and nutrient treatment on the probability of seedling survival. To avoid an excessively complicated analysis framework and to facilitate a clearer presentation of results, this analysis was carried out for each species separately using generalised linear models with binomial error distributions. This procedure involved the construction of two models for each species. The first model, which assessed the overall effect of seedling size on post-fire survival, pooled data across nutrient treatments for a given species and included seedling survival as a binary response variable, and seedling size as a predictor. The second model assessed the effects of nutrient addition on seedling survival and included nutrient treatments and plant size as predictors. This second model was subjected to a backward stepwise elimination of terms to arrive at a minimum acceptable model.

All statistical analyses were carried out in R (R Core Team 2014). We used the lme4 package (Bates et al. 2014) for analyses that involved linear and generalised linear mixed effects models. The statistical significance of parameter estimates of the mixed models were computed using Satterthwaite's approximation of degrees of freedom implemented within the lmerTest package (Kuznetova et al. 2014). However, we place equal emphasis on the magnitude of effects and do not rely solely on computed $P$ values to interpret results.

\section{Results}

$\mathrm{N}$-fixers had marginally higher growth rates compared to non-N-fixers in the control treatment (Fig 1; $P=$ 0.054). Growth rates decreased as a function of initial plant size, but patterns did not differ between functional groups (initial plant size $\mathrm{x}$ functional group: NS). Averaging across all nutrient treatments, the rate of stem height increments in $\mathrm{N}$-fixers was 3.3 times that observed in non- $\mathrm{N}$-fixers in the 15 months between measurements, but growth rates in both functional groups were very variable. Nutrient addition did not affect mean growth rates in either functional group (i.e. nutrient treatment $\mathrm{x}$ functional group: NS, nutrient treatment: NS).

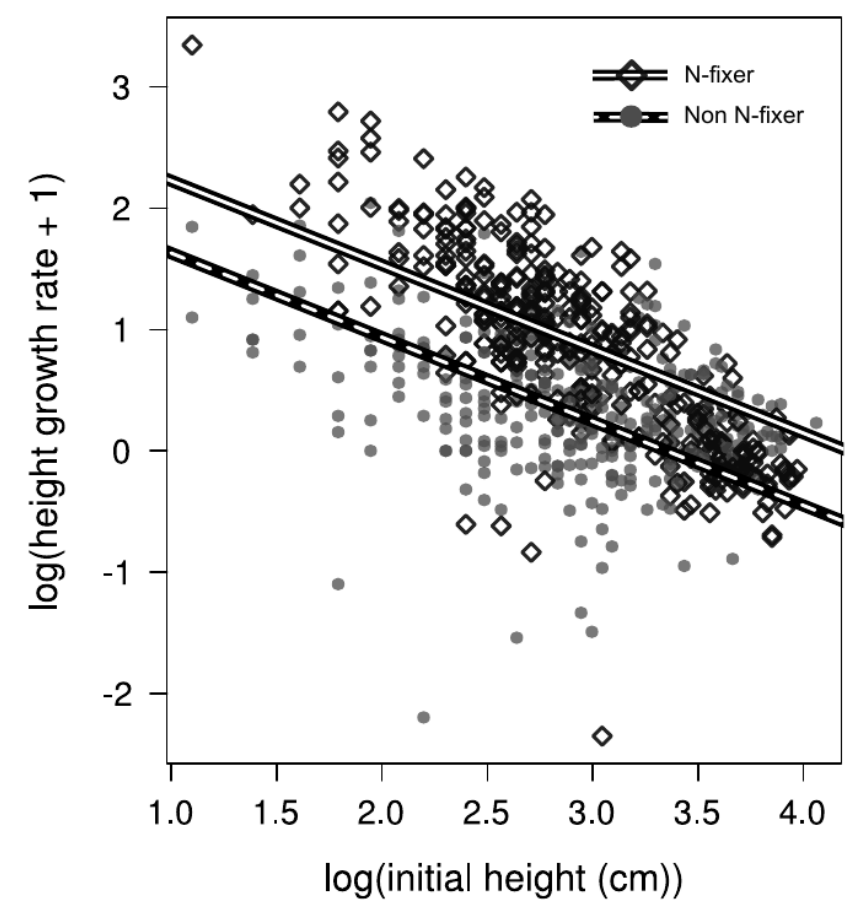

Fig 1. Relationship between relative height growth rate and initial seedling height in the control treatment (no nutrient addition). $\mathrm{N}$ fixers show marginally faster mean growth rates compared to non-N-fixers $(P=0.054)$ 
$\mathrm{N}$-fixers in general had greater growth rates amongst the fastest growing individuals in terms of both stem height (Fig 2a) and diameter growth (Fig 2b). The only exception to this was A. ferruginea which had very slow height growth rates (Fig 2a). Fertilisation resulted in large changes in the growth rates of the fastest growing individuals. Amongst $\mathrm{N}$-fixers, nutrient addition largely increased stem height growth rates (positive LRRs where CIs did not overlap with zero), except in D. latifolia which showed a small decline (Fig 2a). We also note that the large increases observed for $A$. ferruginea could be an artefact of slow growth rates for this species in general (Fig 2a). With respect to stem diameter growth rates, $\mathrm{N}$-fixers showed a more mixed response to fertilisation across species. However, non-N-fixers showed consistent increases in stem diameter growth rates (Fig 2b). As a consequence, in all four non-N-fixing species, greater stem diameters were observed in nutrient addition treatments, especially with $\mathrm{N}$ addition, compared to the maximum stem diameter achieved in the control treatment for each species (Fig 3).
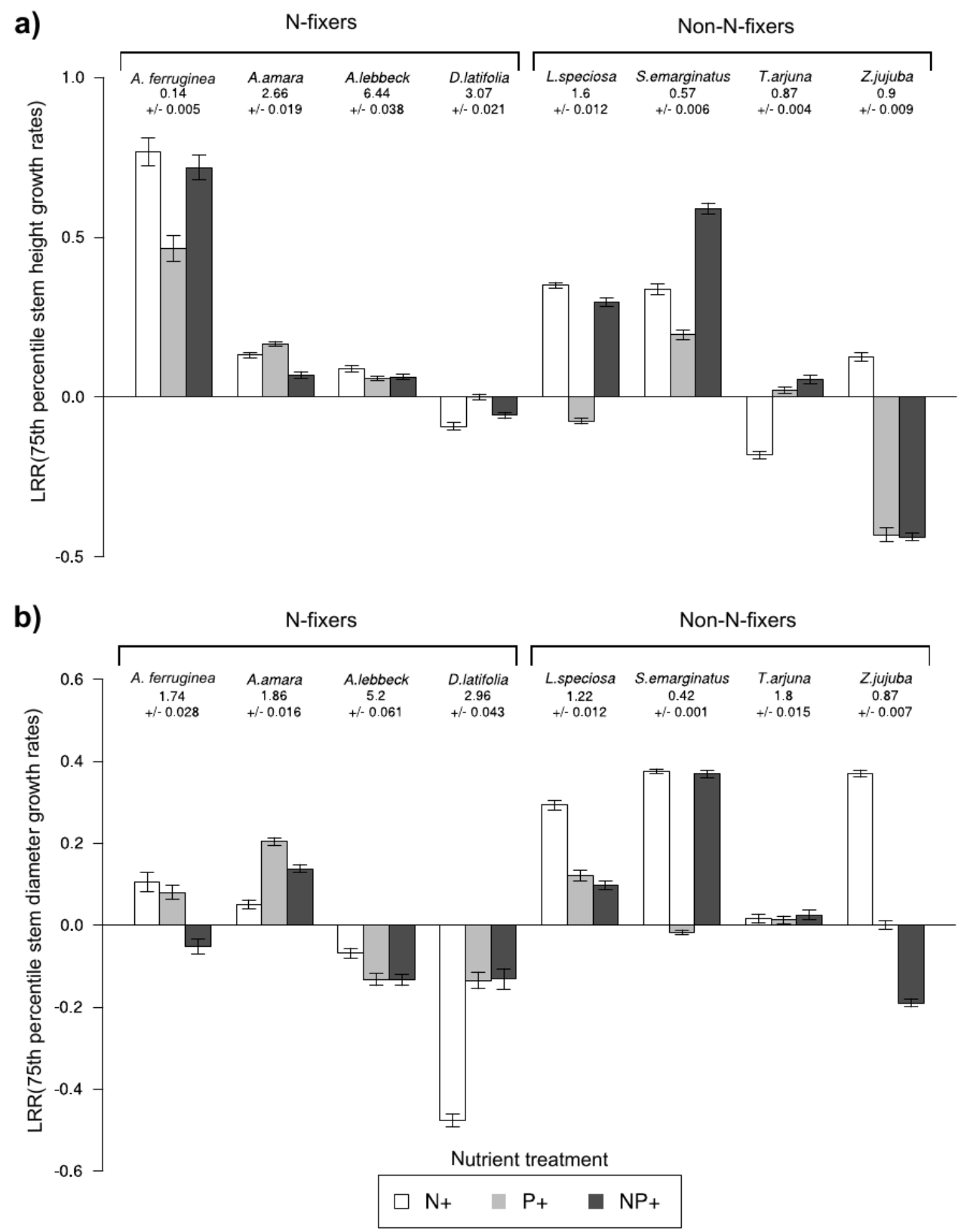

Fig 2. Bootstrapped log response ratios (LRR) of the $75^{\text {th }}$ percentile growth rates for stem height (a) and stem diameter

(b). Error bars indicate $95 \%$ confidence intervals. Values quotes below species names are bootstrapped mean $75^{\text {th }}$ percentile growth rates observed in the control treatment (no nutrient addition) for the respective species and associated $95 \%$ confidence intervals. 

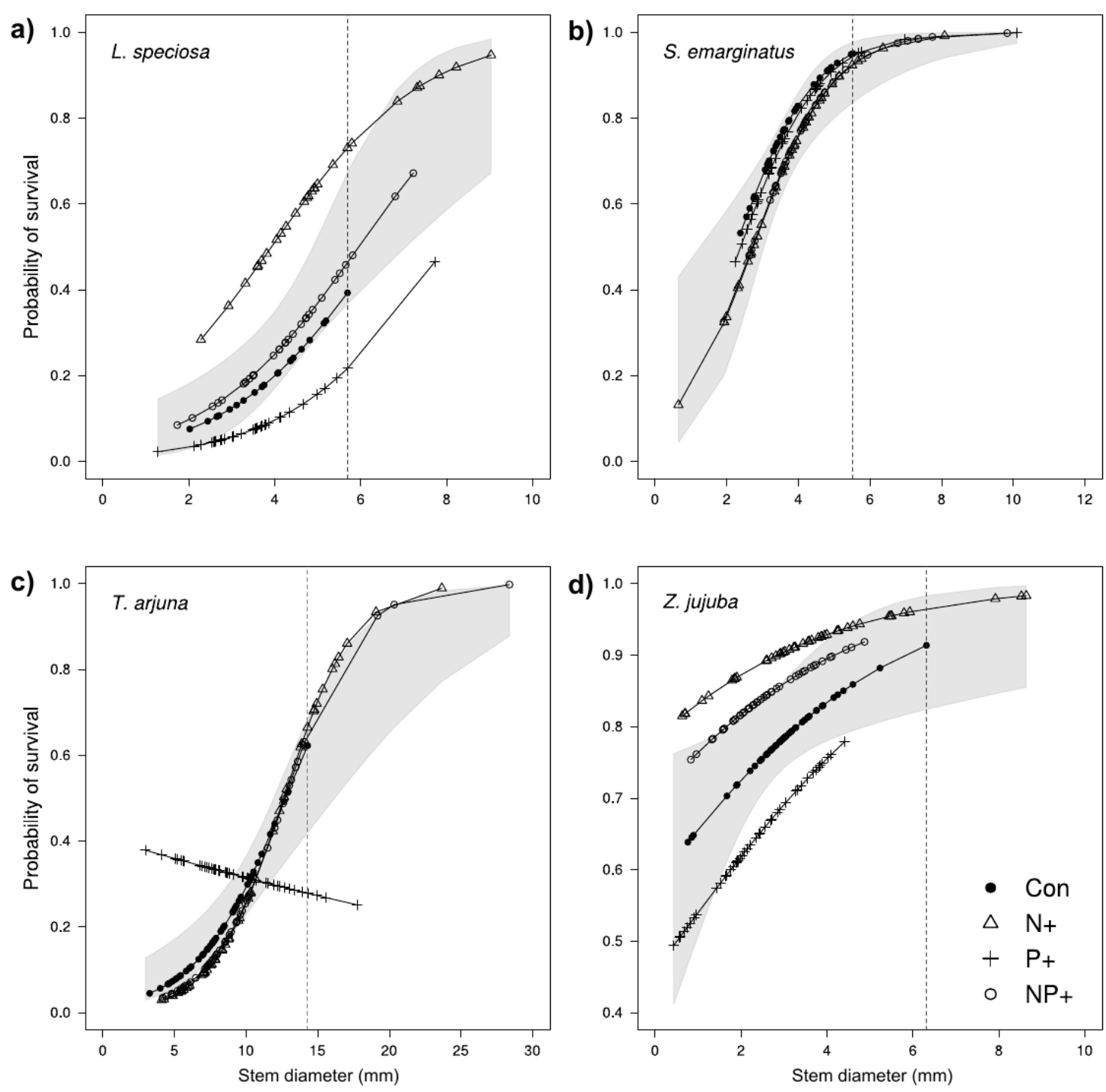

Fig 3. Relationship between seedling pre-burn stem diameter and fitted probability of survival when burned (generalised linear model with binomial error distributions) for each non-N-fixing species - L. speciosa (a), S. emarginatus (b), T. arjuna (c) and Z. jujuba (d). Shaded regions represent the $95 \%$ confidence bounds of the relationship between stem diameter and survival probabilities when all nutrient treatments are pooled. The vertical dotted lines indicate the maximum stem diameter observed in the control treatment (no nutrient addition) for each species.

Seedling survival was in general very high in N-fixers. In the unburned treatment, $99 \%$ of $\mathrm{N}$-fixers survived compared to $87 \%$ in the case of non-N-fixers (Fig 4a-b; $P<0.001$ ). Amongst interactions included in the model, the three-way interaction between functional group, nutrient treatment and fire treatment was not significant, and only the two-way interaction between functional group and fire treatment was a significant predictor of seedling survival $\left(P<0.001 ; d f_{1,384}\right)$. Burning had no effect on $\mathrm{N}$-fixer survival which remained high $(99 \%$ resprouted following burning; Fig $4 \mathrm{a})$, but significantly reduced survival in non-N-fixers with only $51 \%$ resprouting following burning (Fig $4 \mathrm{~b} ; P<0.001$ ). Of the 1364 seedlings exposed to fire, only four individuals, all of which were N-fixers, reached sufficient height $(>140 \mathrm{~cm})$ to escape top-kill. Thus, firemediated mortality was almost exclusively restricted to non- $\mathrm{N}$-fixers. Nutrient treatments did not affect seedling survival in either functional group (Fig 4a,b), though high variation in survival was observed in non-N-fixers exposed to $\mathrm{N}$ addition (Fig $4 \mathrm{~b}$ ). Grass and forb biomass production was not affected by fertilisation. Therefore, nutrient deposition at application rates used in this experiment did not influence fuel loads, and hence, fire intensity. 
a)

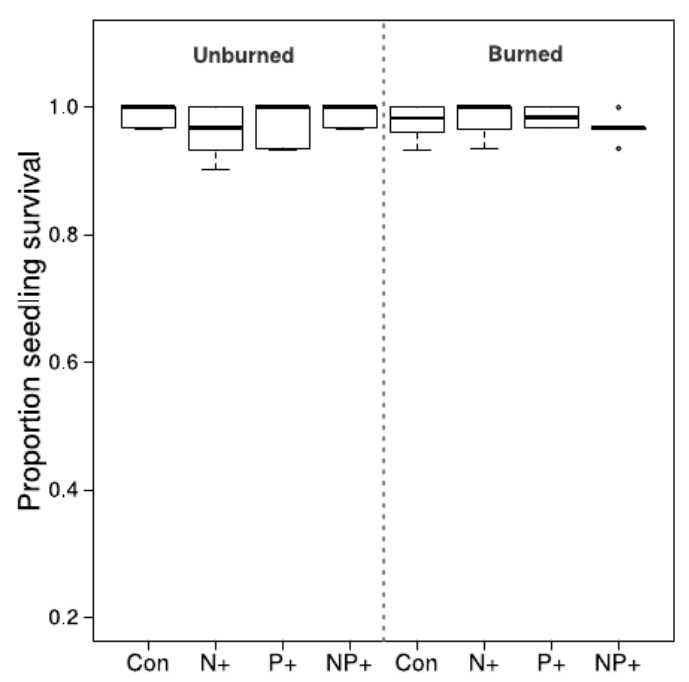

b)

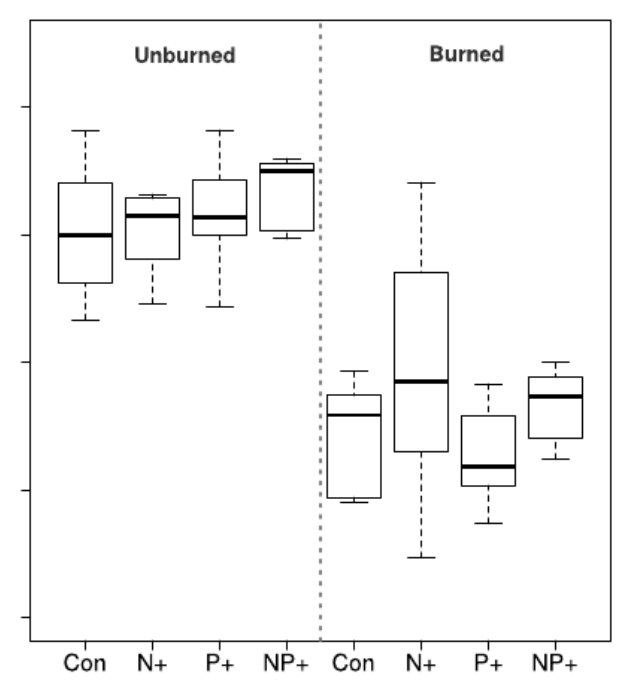

Treatments

Fig 4. Observed seedling survival in unburned and burned treatments for N-fixers (a) and non-N-fixers (b).

In non-N-fixing species, increasing stem diameter and height (data not shown) significantly increased probability of post-fire seedling survival $(P<0.001$ for all species; Fig 3a-d). The only exception to this relationship was observed in $T$. arjuna seedlings exposed to $\mathrm{P}$ addition, where survival declined marginally with increasing stem diameter (Fig 3c). In non-N-fixers, nutrient addition, especially N, increased stem diameter growth rates of the fastest growing individuals (Fig $2 b$ ) and resulted in seedlings reaching larger stem diameters in fertilised plots compared to their respective controls (Fig 3a-d). In turn, these larger seedlings had higher survival probabilities. In contrast, in the case of $\mathrm{N}$-fixers, there was no relationship evident between post-fire survival and plant size (i.e. stem height and diameter) given that virtually all individuals survived fire.

\section{Discussion}

$\mathrm{N}$-fixing tropical dry forest seedlings showed faster growth rates compared to non-N-fixers. N-fixers also demonstrated a substantially greater ability to survive fires. Nutrient addition did not affect mean seedling growth rates in either functional group in this study. However, fertilisation had a strong influence on the growth rates of the fastest growing seedlings in both functional groups. Consistent increases in stem diameter growth rates of the fastest growing individuals of non-N-fixing species allowed these seedlings to attain larger stem diameters, which in turn, increased their survival probabilities following fires. Although N-fixing species were largely unaffected by either fire or nutrient addition, with virtually all individuals surviving, the increased growth and survival probabilities of the fastest growing non- $\mathrm{N}$-fixers with nutrient addition suggests that non- $\mathrm{N}$-fixers may benefit from increased nutrient deposition in the future.

In the control treatment, i.e. with no added nutrients, $\mathrm{N}$-fixers showed marginally higher relative growth rates compared to non-N-fixers. Faster growth rates in N-fixers could be attributed to greater foliar $\mathrm{N}$ content (Khurana and Singh 2004; Wright et al. 2004; Powers and Tiffin 2010; Orwin et al. 2010; Reich 2014) afforded by their association with $\mathrm{N}$-fixing bacteria in root nodules. As a consequence, $\mathrm{N}$-fixers were taller at the time of burning and showed higher post-fire survival compared to non- $\mathrm{N}$-fixers. $\mathrm{N}$ and $\mathrm{P}$ addition in general did not affect mean seedling growth rates in both functional groups. However, fertilisation did result in changes in growth rates of the fastest growing individuals of a species, especially for non-N-fixers with $\mathrm{N}$ 
addition. Wakeling et al. (2011) argued that growth rates of the fastest growing individuals (the fastest 5\%), as opposed to mean growth rates, were better predictors of the number of individuals escaping fires, and consequently, of observed tree densities in an African savanna (Wakeling et al. 2011). Hence, non-N-fixers are likely to benefit from enhanced in $\mathrm{N}$ deposition through consistent increases in the growth rates of the fastest growing individuals and resulting increases in post-fire survival.

In contrast to many previous studies (Fynn and O'Connor 2005; Craine et al. 2008; Kambatuku et al. 2012; Cramer et al. 2012; Vadigi and Ward 2012; Verma et al. 2014), fertilisation did not influence mean seedling growth rates and herbaceous biomass production in this experiment. Studies which have reported increases in herbaceous production and tree seedling growth rates previously, have used $\mathrm{N}$ application rates that were between three and six times higher than that used here (Kambatuku et al. 2012; Cramer et al. 2012; Verma et al. 2014). Our results are, however, consistent with other studies where nutrient application rates were lower (Cramer et al. 2010; Barbosa et al. 2014b). This suggests that $\mathrm{N}$ and $\mathrm{P}$ deposition, at rates expected by 2030, are unlikely to have pronounced short-term effects on tree recruitment in Indian savannas and tropical dry forests with respect to tree seedling growth rates and accumulation of ecosystem fuel loads.

$\mathrm{N}$-fixers demonstrated very high levels of seedling survival that was unaffected by nutrient or fire treatments. Seedling mortality was almost exclusively restricted to non-N-fixers. Survival of non-N-fixers was significantly lower than $\mathrm{N}$-fixers in the unburned treatment (Fig 4) and declined substantially following burning. In fact, only half of non-N-fixers survived fire, compared to $99 \%$ of $\mathrm{N}$-fixers. These results reiterate the important role fire plays in restricting tree recruitment, and hence, tree cover in this ecosystem that numerous studies have previously highlighted (Bond and van Wilgen 1996; Higgins et al. 2000; Sankaran et al. 2005; Bond 2008). In addition, it also demonstrates the role of differential susceptibility to fire-mediated mortality between $\mathrm{N}$-fixers and non-N-fixers in shaping tree community composition, an aspect that has thus far not been adequately addressed.

One reason for greater survival of $\mathrm{N}$-fixers could be their faster growth rates compared to non-N-fixers, which allows them to reach larger seedling sizes before the start of the fire season, which in turn confers them with increased post-fire survival (Trollope 1984; Gignoux et al. 1997; Hoffmann and Solbrig 2003; Bond 2008; Lawes et al. 2011; Wakeling et al. 2011). Further, N-fixing tropical savanna and dry forest tree seedlings have been shown to partition relatively greater amounts of biomass to roots, as well as invest in higher root storage carbohydrate concentrations (Varma et al. 2018). This below-ground investment is positively associated with post-fire resprouting (Hoffmann et al. 2000; Bell 2001; Bond et al. 2003b; Bond and Midgley 2003; Clarke and Knox 2009; Wigley et al. 2009; Schutz et al. 2009; Clarke et al. 2013), which can promote survival in $\mathrm{N}$-fixers.

Larger stem diameters were positively associated with post-fire survival probabilities amongst non-N-fixing species. With nutrient addition, and in particular $\mathrm{N}$ addition, non- $\mathrm{N}$-fixers attained larger maximum stem diameters compared to individuals from control treatments, a result of consistent increases in stem diameter growth rates of the fastest growing individuals with $\mathrm{N}$ addition. On average, across the four non- $\mathrm{N}$-fixing species, $16 \%$ of individuals had greater stem diameters in the $\mathrm{N}$ addition treatment compared to the maximum observed in the control treatment. Consequently, these individuals also had higher post-fire survival probabilities. As N-fixers displayed very high baseline rates of post-fire survival, they had no room for improved survival with increases in seedling size. Therefore, with nutrient deposition, the community of surviving seedlings or resprouts could see an increase in the relative abundance of non- $\mathrm{N}$-fixers.

In addition to fire, herbivory constitutes another major disturbance agent in this ecosystem that can influence recruitment and composition of tree communities (Frost et al. 1986; Sankaran et al. 2004, 2008). Herbivory can interact with fires to impose a stronger control on tree cover, compared to that exerted by either disturbance agent independently (Staver et al. 2009). Susceptibility to herbivory, as well as plant investment into herbivory defence can be mediated by nutrient availability (Bryant et al. 1983; Endara and Coley 2011; Vadigi and Ward 2012). Hence, further research on the impacts of nutrient deposition on tropical dry forest 
tree recruitment would benefit from the explicit consideration of the interaction between nutrient deposition, fire regimes and herbivory. Additionally, in disturbance prone ecosystems, post-disturbance recovery of tree seedlings is a key process that influences tree recruitment, as it can play an important role in determining susceptibility of plants to subsequent disturbance events (Bond and Midgley 2001; Wigley et al. 2009; Schutz et al. 2009). Previous studies have shown that post-disturbance resprouts can differ substantially from seedlings in terms of growth (Hoffmann and Solbrig 2003; Grady and Hoffmann 2012). However, differences in patterns of recovery between species and functional groups, and the influence of nutrient availability is relatively unexplored.

Atmospheric nutrient deposition has the potential to alter vegetation communities through direct effects of fertilisation on growth and productivity of plants and indirectly, by modifying properties of disturbance regimes, as well as the susceptibility of plants to disturbance events. Quantifying these effects within the context of processes that shape vegetation communities is critical towards assessing the future trajectory of ecosystems. In this study we demonstrated that greater seedling growth rates and consequently, high post-fire survival in $\mathrm{N}$-fixing species compared to non-N-fixers may play an important role in structuring tree communities in tropical dry forests. Rates of nutrient deposition in the near future are unlikely to result in large modifications in this baseline advantage for $\mathrm{N}$-fixers in our study area. However, even with conservative rates of nutrient deposition, increased nutrient availability (especially $\mathrm{N}$ ) has the potential to modify seedling growth rates. In non-N-fixers, this leads to increases in post-fire survival probabilities. As $\mathrm{N}$-fixers maintain high levels of post-fire survival, that are unaffected by nutrient addition, the resprouting community may see increases in the relative representation of non-N-fixers, that in the long-term, could be reflected in adult tree assemblages.

\section{Acknowledgements}

We would like to thank Kavita Isvaran, Suhel Quader and Jayashree Ratnam for their input during planning and execution of the experiment. We also thank Dr. Ganesh Babu and Umesh VJ at the Foundation for the Revitalisation of Local Health and Tradition (FRLHT), Bangalore, for providing the tree seedlings, and Manjunatha HC, Meenakshi HJ, and Chandregowda $\mathrm{J}$ for the use of their land for the experiment. Our gratitude to our field assistants Mahesh HK, Bomrai HK and Mahadev HK, and also to Hemanth Kumar HV, Anil PA, Harinandanan PV, Chengappa SK, Rutuja Dhamale, Mayank Kohli, Nandita Nataraj and Prashanth Gowda for their assistance during the experiment. Funding for this work was provided by the National Centre for Biological Sciences (NCBS), Bangalore. This manuscript was greatly improved by comments from Anand M Osuri, Fiona Savory, Sumanta Baghchi and Edmund C February.

\section{References}

Barbosa ERM, van Langevelde F, Tomlinson KW, Carvalheiro LG, Kirkman K, Bie S de, Prins HHT (2014a) Tree species from different functional groups respond differently to environmental changes during establishment. Oecologia 174:1345-1357. doi: 10.1007/s00442-013-2853-y

Barbosa ERM, Tomlinson KW, Carvalheiro LG, Kirkman K, de Bie S, Prins HHT, van Langevelde F (2014b) Short-term effect of nutrient availability and rainfall distribution on biomass production and leaf nutrient content of savanna tree species. PLoS ONE 9:e92619. doi: 10.1371/journal.pone.0092619

Barbosa PM, Stroppiana D, Grégoire J-M, Cardoso Pereira JM (1999) An assessment of vegetation fire in Africa (1981-1991): Burned areas, burned biomass, and atmospheric emissions. Glob Biogeochem Cycles 13:933-950. doi: 10.1029/1999GB900042 
Bates D, Maechler M, Bolker BM, Walker S (2014) lme4: Linear mixed-effects models using Eigen and S4. J Stat Softw ArXiv e-print http://arxiv.org/abs/1406.5823

Bell DT (2001) Ecological response syndromes in the flora of southwestern Western Australia: Fire resprouters versus reseeders. Bot Rev 67:417-440. doi: 10.1007/BF02857891

Bobbink R, Hicks K, Galloway J, Spranger T, Alkemade R, Ashmore M, Bustamante M, Cinderby S, Davidson E, Dentener F, Emmett B, Erisman JW, Fenn M, Gilliam F, Nordin A, Pardo L, De Vries W (2010) Global assessment of nitrogen deposition effects on terrestrial plant diversity: a synthesis. Ecol Appl 20:30-59. doi: 10.1890/08-1140.1

Bobbink R, Lamers LPM (2002) Effects of increased nitrogen deposition. In: Air pollution and plant life, 2nd Edition. John Wiley and Sons, Chichester, UK, pp 201-235

Bond WJ (2008) What limits trees in c4 grasslands and savannas? Annu Rev Ecol Evol Syst 39:641-659

Bond WJ, Midgley GF, Woodward FI (2003a) The importance of low atmospheric $\mathrm{CO}_{2}$ and fire in promoting the spread of grasslands and savannas. Glob Change Biol 9:973-982. doi: 10.1046/j.13652486.2003.00577.x

Bond WJ, Midgley GF, Woodward FI, Hoffman MT, Cowling RM (2003b) What controls South African vegetation — climate or fire? South Afr J Bot 69:79-91. doi: 10.1016/S0254-6299(15)30362-8

Bond WJ, Midgley JJ (2001) Ecology of sprouting in woody plants: the persistence niche. Trends Ecol Evol 16:45-51. doi: 10.1016/S0169-5347(00)02033-4

Bond WJ, Midgley JJ (2003) The evolutionary ecology of sprouting in woody plants. Int J Plant Sci 164:S103-S114. doi: 10.1086/374191

Bond WJ, Parr CL (2010) Beyond the forest edge: Ecology, diversity and conservation of the grassy biomes. Biol Conserv 143:2395-2404. doi: 10.1016/j.biocon.2009.12.012

Bond WJ, van Wilgen BW (1996) Fire and plants. Chapman and Hall

Bond WJ, Woodward FI, Midgley GF (2005) The global distribution of ecosystems in a world without fire. New Phytol 165:525-538. doi: 10.1111/j.1469-8137.2004.01252.x

Bryant JP, Chapin FS, Klein DR (1983) Carbon/nutrient balance of boreal plants in relation to vertebrate herbivory. Oikos 40:357-368. doi: 10.2307/3544308

Clark CM, Tilman D (2008) Loss of plant species after chronic low-level nitrogen deposition to prairie grasslands. Nature 451:712-715. doi: 10.1038/nature06503

Clarke PJ, Knox KJE (2009) Trade-offs in resource allocation that favour resprouting affect the competitive ability of woody seedlings in grassy communities. J Ecol 97:1374-1382. doi: 10.1111/j.13652745.2009.01556.x

Clarke PJ, Lawes MJ, Midgley JJ, Lamont BB, Ojeda F, Burrows GE, Enright NJ, Knox KJE (2013) Resprouting as a key functional trait: how buds, protection and resources drive persistence after fire. New Phytol 197:19-35. doi: 10.1111/nph.12001

Craine JM, Morrow C, Stock WD (2008) Nutrient concentration ratios and co-limitation in South African grasslands. New Phytol 179:829-836. doi: 10.1111/j.1469-8137.2008.02513.x

Cramer MD, Bond WJ (2013) N-fertilization does not alleviate grass competition induced reduction of growth of African savanna species. Plant Soil 366:563-574. doi: 10.1007/s11104-012-1456-4 
Cramer MD, Chimphango SBM, Van Cauter A, Waldram MS, Bond WJ (2007) Grass competition induces $\mathrm{N}_{2}$ fixation in some species of African Acacia. J Ecol 95:1123-1133. doi: 10.1111/j.13652745.2007.01285.x

Cramer MD, Van Cauter A, Bond WJ (2010) Growth of $\mathrm{N}_{2}$-fixing African savanna Acacia species is constrained by below-ground competition with grass. J Ecol 98:156-167. doi: 10.1111/j.13652745.2009.01594.x

Cramer MD, Wakeling JL, Bond WJ (2012) Belowground competitive suppression of seedling growth by grass in an African savanna. Plant Ecol 213:1655-1666. doi: 10.1007/s11258-012-0120-7

Dantas V de L, Batalha MA, França H, Pausas JG (2015) Resource availability shapes fire-filtered savannas. J Veg Sci 26:395-403. doi: 10.1111/jvs.12247

Dentener F, Drevet J, Lamarque JF, Bey I, Eickhout B, Fiore AM, Hauglustaine D, Horowitz LW, Krol M, Kulshrestha UC, Lawrence M, Galy-Lacaux C, Rast S, Shindell D, Stevenson D, Van Noije T, Atherton C, Bell N, Bergman D, Butler T, Cofala J, Collins B, Doherty R, Ellingsen K, Galloway J, Gauss M, Montanaro V, Müller JF, Pitari G, Rodriguez J, Sanderson M, Solmon F, Strahan S, Schultz M, Sudo K, Szopa S, Wild O (2006) Nitrogen and sulfur deposition on regional and global scales: A multimodel evaluation. Glob Biogeochem Cycles 20:GB4003. doi: $10.1029 / 2005$ GB002672

Du E, Liu X (2014) High rates of wet nitrogen deposition in china: a synthesis. In: Sutton MA, Mason KE, Sheppard LJ, Sverdrup H, Haeuber R, Hicks WK (eds) Nitrogen deposition, critical loads and biodiversity. Springer Netherlands, pp 49-56

Dwyer E, Grégoire J-M, Malingreau J-P (1998) A global analysis of vegetation fires using satellite images: Spatial and temporal dynamics. Ambio 27:175-181

Dwyer E, Pereira JMC, Grégoire J-M, DaCamara CC (2000) Characterization of the spatio-temporal patterns of global fire activity using satellite imagery for the period April 1992 to March 1993. J Biogeogr 27:57-69. doi: 10.1046/j.1365-2699.2000.00339.x

Edwards EJ, Osborne CP, Strömberg CAE, Smith SA, Consortium CG (2010) The origins of $\mathrm{C}_{4}$ grasslands: integrating evolutionary and ecosystem science. Science 328:587-591. doi: $10.1126 /$ science. 1177216

Elser JJ, Bracken MES, Cleland EE, Gruner DS, Harpole WS, Hillebrand H, Ngai JT, Seabloom EW, Shurin JB, Smith JE (2007) Global analysis of nitrogen and phosphorus limitation of primary producers in freshwater, marine and terrestrial ecosystems. Ecol Lett 10:1135-1142. doi: 10.1111/j.14610248.2007.01113.x

Endara M-J, Coley PD (2011) The resource availability hypothesis revisited: a meta-analysis. Funct Ecol 25:389-398. doi: 10.1111/j.1365-2435.2010.01803.x

Falkowski P, Scholes RJ, Boyle E, Canadell J, Canfield D, Elser J, Gruber N, Hibbard K, Högberg P, Linder S, Mackenzie FT, Moore III B, Pedersen T, Rosenthal Y, Seitzinger S, Smetacek V, Steffen W (2000) The global carbon cycle: a test of our knowledge of earth as a system. Science 290:291-296. doi: $10.1126 /$ science.290.5490.291

Field CB, Behrenfeld MJ, Randerson JT, Falkowski P (1998) Primary production of the biosphere: integrating terrestrial and oceanic components. Science 281:237-240. doi: $10.1126 /$ science. 281.5374 .237 
Frost PGH, Medina E, Menaut J., Solbrig O, Swift M, Walker BH (1986) Response of savannas to stress and disturbance. Biol. Int. Spec. Issue 10 IUBS Paris

Fynn RWS, O'Connor TG (2005) Determinants of community organization of a South African mesic grassland. J Veg Sci 16:93-102. doi: 10.1111/j.1654-1103.2005.tb02342.x

Galloway JN, Dentener FJ, Capone DG, Boyer EW, Howarth RW, Seitzinger SP, Asner GP, Cleveland CC, Green PA, Holland EA, Karl DM, Michaels AF, Porter JH, Townsend AR, Vöosmarty CJ (2004) Nitrogen cycles: past, present, and future. Biogeochemistry 70:153-226. doi: 10.1007/s10533-0040370-0

Galloway JN, Townsend AR, Erisman JW, Bekunda M, Cai Z, Freney JR, Martinelli LA, Seitzinger SP, Sutton MA (2008) Transformation of the nitrogen cycle: recent trends, questions, and potential solutions. Science 320:889-892. doi: 10.1126/science.1136674

Gignoux J, Clobert J, Menaut J-C (1997) Alternative fire resistance strategies in savanna trees. Oecologia 110:576-583. doi: 10.1007/s004420050198

Grady JM, Hoffmann WA (2012) Caught in a fire trap: Recurring fire creates stable size equilibria in woody resprouters. Ecology 93:2052-2060. doi: 10.1890/12-0354.1

Heil GW, Diemont WH (1983) Raised nutrient levels change heathland into grassland. Vegetatio 53:113120. doi: 10.1007/BF00043031

Hermans C, Hammond JP, White PJ, Verbruggen N (2006) How do plants respond to nutrient shortage by biomass allocation? Trends Plant Sci 11:610-617. doi: 10.1016/j.tplants.2006.10.007

Higgins SI, Bond WJ, February EC, Bronn A, Euston-Brown DIW, Enslin B, Govender N, Rademan L, O'Regan S, Potgieter ALF, Scheiter S, Sowry R, Trollope L, Trollope WSW (2007) Effects of four decades of fire manipulation on woody vegetation structure in savanna. Ecology 88:1119-1125. doi: $10.1890 / 06-1664$

Higgins SI, Bond WJ, Trollope WSW (2000) Fire, resprouting and variability: a recipe for grass-tree coexistence in savanna. J Ecol 88:213-229. doi: 10.1046/j.1365-2745.2000.00435.x

Hoffmann WA, Bazzaz FA, Chatterton NJ, Harrison PA, Jackson RB (2000) Elevated $\mathrm{CO}_{2}$ enhances resprouting of a tropical savanna tree. Oecologia 123:312-317. doi: 10.1007/s004420051017

Hoffmann WA, Geiger EL, Gotsch SG, Rossatto DR, Silva LCR, Lau OL, Haridasan M, Franco AC (2012) Ecological thresholds at the savanna-forest boundary: how plant traits, resources and fire govern the distribution of tropical biomes. Ecol Lett 15:759-768. doi: 10.1111/j.1461-0248.2012.01789.x

Hoffmann WA, Solbrig OT (2003) The role of topkill in the differential response of savanna woody species to fire. For Ecol Manag 180:273-286. doi: 10.1016/S0378-1127(02)00566-2

House JI, Archer S, Breshears DD, Scholes RJ, NCEAS Tree-Grass Interactions Participants (2003) Conundrums in mixed woody-herbaceous plant systems. J Biogeogr 30:1763-1777. doi: 10.1046/j.1365-2699.2003.00873.x

Huante P, Rincon E, Acosta I (1995a) Nutrient availability and growth rate of 34 Woody Species from a tropical deciduous forest in Mexico. Funct Ecol 9:849-858. doi: 10.2307/2389982

Huante P, Rincon E, Chapin FS (1995b) Responses to phosphorus of contrasting successional tree-seedling species from the tropical deciduous forest of Mexico. Funct Ecol 9:760-766. doi: 10.2307/2390249 
Kambatuku JR, Cramer MD, Ward D (2012) Nitrogen fertilisation reduces grass-induced $\mathrm{N}_{2}$ fixation of tree seedlings from semi-arid savannas. Plant Soil 365:307-320. doi: 10.1007/s11104-012-1389-y

Khurana E, Singh JS (2004) Impact of elevated nitrogen inputs on seedling growth of five dry tropical tree species as affected by life-history traits. Can J Bot 82:158-167. doi: 10.1139/b03-132

Knox KJE, Clarke PJ (2005) Nutrient availability induces contrasting allocation and starch formation in resprouting and obligate seeding shrubs. Funct Ecol 19:690-698. doi: 10.1111/j.13652435.2005.01006.x

Kodandapani N, Cochrane MA, Sukumar R (2008) A comparative analysis of spatial, temporal, and ecological characteristics of forest fires in seasonally dry tropical ecosystems in the Western Ghats, India. For Ecol Manag 256:607-617. doi: 10.1016/j.foreco.2008.05.006

Kraaij T, Ward D (2006) Effects of rain, nitrogen, fire and grazing on tree recruitment and early survival in bush-encroached savanna, South Africa. Plant Ecol 186:235-246. doi: 10.1007/s11258-006-9125-4

Kumar R, Shahabuddin G (2005) Effects of biomass extraction on vegetation structure, diversity and composition of forests in Sariska Tiger Reserve, India. Environ Conserv 32:248-259. doi: $10.1017 / \mathrm{S} 0376892905002316$

Kuznetova A, Brockhoff P., Christensen RJ. (2014) lmerTest: Tests for random and fixed effects for linear mixed effect models (lmer objects of lme4 package). R package version 2.0-11

Lamont BB, Wiens D (2003) Are seed set and speciation rates always low among species that resprout after fire, and why? Evol Ecol 17:277-292. doi: 10.1023/A:1025535223021

Lawes MJ, Adie H, Russell-Smith J, Murphy B, Midgley JJ (2011) How do small savanna trees avoid stem mortality by fire? The roles of stem diameter, height and bark thickness. Ecosphere 2:1-13. doi: 10.1890/ES10-00204.1

Lee M, Manning P, Rist J, Power SA, Marsh C (2010) A global comparison of grassland biomass responses to $\mathrm{CO}_{2}$ and nitrogen enrichment. Philos Trans R Soc Lond B Biol Sci 365:2047-2056. doi: $10.1098 /$ rstb.2010.0028

Lehmann CER, Anderson TM, Sankaran M, Higgins SI, Archibald S, Hoffmann WA, Hanan NP, Williams RJ, Fensham RJ, Felfili J, Hutley LB, Ratnam J, Jose JS, Montes R, Franklin D, Russell-Smith J, Ryan CM, Durigan G, Hiernaux P, Haidar R, Bowman DMJS, Bond WJ (2014) Savanna vegetationfire-climate relationships differ among continents. Science 343:548-552. doi: $10.1126 /$ science. 1247355

Lehmann CER, Prior LD, Bowman DMJS (2009a) Fire controls population structure in four dominant tree species in a tropical savanna. Oecologia 161:505-515. doi: 10.1007/s00442-009-1395-9

Lehmann CER, Ratnam J, Hutley LB (2009b) Which of these continents is not like the other? Comparisons of tropical savanna systems: key questions and challenges. New Phytol 181:508-511. doi: 10.1111/j.1469-8137.2009.02734.x

Lu X, Mo J, Gilliam FS, Zhou G, Fang Y (2010) Effects of experimental nitrogen additions on plant diversity in an old-growth tropical forest. Glob Change Biol 16:2688-2700. doi: 10.1111/j.13652486.2010.02174.x

Mahowald N, Jickells TD, Baker AR, Artaxo P, Benitez-Nelson CR, Bergametti G, Bond TC, Chen Y, Cohen DD, Herut B, Kubilay N, Losno R, Luo C, Maenhaut W, McGee KA, Okin GS, Siefert RL, Tsukuda S (2008) Global distribution of atmospheric phosphorus sources, concentrations and 
deposition rates, and anthropogenic impacts. Glob Biogeochem Cycles 22:GB4026. doi: 10.1029/2008GB003240

Matson PA, McDowell WH, Townsend AR, Vitousek PM (1999) The globalization of N deposition: ecosystem consequences in tropical environments. Biogeochemistry 46:67-83. doi: 10.1023/A:1006152112852

McShea WJ, Davies SJ, Bhumpakphan N (2011) The ecology and conservation of seasonally dry forests in Asia. Smithsonian Institution Scholarly Press

Murphy PG, Lugo AE (1986) Ecology of tropical dry forest. Annu Rev Ecol Syst 17:67-88

Orwin KH, Buckland SM, Johnson D, Turner BL, Smart S, Oakley S, Bardgett RD (2010) Linkages of plant traits to soil properties and the functioning of temperate grassland. J Ecol 98:1074-1083. doi: 10.1111/j.1365-2745.2010.01679.x

Pearson HL, Vitousek PM (2002) Soil phosphorus fractions and symbiotic nitrogen fixation across a substrate-age gradient in Hawaii. Ecosystems 5:587-596. doi: 10.1007/s10021-002-0172-y

Phoenix GK, Emmett BA, Britton AJ, Caporn SJM, Dise NB, Helliwell R, Jones L, Leake JR, Leith ID, Sheppard LJ, Sowerby A, Pilkington MG, Rowe EC, Ashmore MR, Power SA (2012) Impacts of atmospheric nitrogen deposition: responses of multiple plant and soil parameters across contrasting ecosystems in long-term field experiments. Glob Change Biol 18:1197-1215. doi: 10.1111/j.13652486.2011.02590.x

Phoenix GK, Hicks WK, Cinderby S, Kuylenstierna JCI, Stock WD, Dentener FJ, Giller KE, Austin AT, Lefroy RDB, Gimeno BS, Ashmore MR, Ineson P (2006) Atmospheric nitrogen deposition in world biodiversity hotspots: the need for a greater global perspective in assessing $\mathrm{N}$ deposition impacts. Glob Change Biol 12:470-476. doi: 10.1111/j.1365-2486.2006.01104.x

Powers JS, Becklund KK, Gei MG, Iyengar SB, Meyer R, O’ Connell CS, Schilling EM, Smith CM, Waring BG, Werden LK (2015) Nutrient addition effects on tropical dry forests: a mini-review from microbial to ecosystem scales. Biogeoscience 3:34. doi: 10.3389/feart.2015.00034

Powers JS, Tiffin P (2010) Plant functional type classifications in tropical dry forests in Costa Rica: leaf habit versus taxonomic approaches. Funct Ecol 24:927-936. doi: 10.1111/j.1365-2435.2010.01701.x

Puyravaud J-P, Pascal J-P, Dufour C (1994) Ecotone structure as an indicator of changing forest-savanna boundaries (Linganamakki region, southern India). J Biogeogr 21:581-593. doi: 10.2307/2846033

R Core Team (2014) R: A language and environment for statistical computing. R Foundation for Statistical Computing, Vienna, Austria. URL http://www.R-project.org/

Ratnam J, Bond WJ, Fensham RJ, Hoffmann WA, Archibald S, Lehmann CER, Anderson MT, Higgins SI, Sankaran M (2011) When is a 'forest' a savanna, and why does it matter? Glob Ecol Biogeogr 20:653-660. doi: 10.1111/j.1466-8238.2010.00634.x

Reich PB (2014) The world-wide 'fast-slow' plant economics spectrum: a traits manifesto. J Ecol 102:275301. doi: $10.1111 / 1365-2745.12211$

Ryan CM, Williams M (2011) How does fire intensity and frequency affect miombo woodland tree populations and biomass? Ecol Appl 21:48-60. doi: 10.1890/09-1489.1

Sagar R, Singh JS (2004) Local plant species depletion in a tropical dry deciduous forest of northern India. Environ Conserv 31:55-62. doi: 10.1017/S0376892904001031 
Sala OE, Chapin FS, Iii, Armesto JJ, Berlow E, Bloomfield J, Dirzo R, Huber-Sanwald E, Huenneke LF, Jackson RB, Kinzig A, Leemans R, Lodge DM, Mooney HA, Oesterheld M, Poff NL, Sykes MT, Walker BH, Walker M, Wall DH (2000) Global biodiversity scenarios for the year 2100. Science 287:1770-1774. doi: 10.1126/science.287.5459.1770

Sankaran M, Hanan NP, Scholes RJ, Ratnam J, Augustine DJ, Cade BS, Gignoux J, Higgins SI, Le Roux X, Ludwig F, Ardo J, Banyikwa F, Bronn A, Bucini G, Caylor KK, Coughenour MB, Diouf A, Ekaya W, Feral CJ, February EC, Frost PGH, Hiernaux P, Hrabar H, Metzger KL, Prins HHT, Ringrose S, Sea W, Tews J, Worden J, Zambatis N (2005) Determinants of woody cover in African savannas. Nature 438:846-849. doi: 10.1038/nature04070

Sankaran M, Ratnam J, Hanan NP (2004) Tree-grass coexistence in savannas revisited - insights from an examination of assumptions and mechanisms invoked in existing models. Ecol Lett 7:480-490. doi: 10.1111/j.1461-0248.2004.00596.x

Sankaran M, Ratnam J, Hanan NP (2008) Woody cover in African savannas: the role of resources, fire and herbivory. Glob Ecol Biogeogr 17:236-245. doi: 10.1111/j.1466-8238.2007.00360.x

Scholes RJ, Archer SR (1997) Tree-grass interactions in savannas. Annu Rev Ecol Syst 28:517-544

Schutz AEN, Bond WJ, Cramer MD (2009) Juggling carbon: allocation patterns of a dominant tree in a fireprone savanna. Oecologia 160:235-246. doi: 10.1007/s00442-009-1293-1

Siddique I, Vieira ICG, Schmidt S, Lamb D, Carvalho CJR, Figueiredo R de O, Blomberg S, Davidson EA (2010) Nitrogen and phosphorus additions negatively affect tree species diversity in tropical forest regrowth trajectories. Ecology 91:2121-2131. doi: 10.1890/09-0636.1

Staver AC, Bond WJ, Stock WD, van Rensburg SJ, Waldram MS (2009) Browsing and fire interact to suppress tree density in an African savanna. Ecol Appl 19:1909-1919. doi: 10.1890/08-1907.1

Stevens CJ, Dise NB, Gowing DJG, Mountford JO (2006) Loss of forb diversity in relation to nitrogen deposition in the UK: regional trends and potential controls. Glob Change Biol 12:1823-1833. doi: 10.1111/j.1365-2486.2006.01217.x

Stevens CJ, Dise NB, Mountford JO, Gowing DJ (2004) Impact of nitrogen deposition on the species richness of grasslands. Science 303:1876-1879. doi: 10.1126/science.1094678

Stevens CJ, Duprè C, Dorland E, Gaudnik C, Gowing DJG, Bleeker A, Diekmann M, Alard D, Bobbink R, Fowler D, Corcket E, Mountford JO, Vandvik V, Aarrestad PA, Muller S, Dise NB (2010) Nitrogen deposition threatens species richness of grasslands across Europe. Environ Pollut 158:2940-2945. doi: 10.1016/j.envpol.2010.06.006

Strengbom J, Nordin A, Näsholm T, Ericson L (2002) Parasitic fungus mediates change in nitrogen-exposed boreal forest vegetation. J Ecol 90:61-67. doi: 10.1046/j.0022-0477.2001.00629.x

Tansey K, Grégoire J-M, Stroppiana D, Sousa A, Silva J, Pereira JMC, Boschetti L, Maggi M, Brivio PA, Fraser R, Flasse S, Ershov D, Binaghi E, Graetz D, Peduzzi P (2004) Vegetation burning in the year 2000: Global burned area estimates from SPOT VEGETATION data. J Geophys Res Atmospheres 109:D14S03. doi: 10.1029/2003JD003598

Tilman D (1988) Plant strategies and the dynamics and structure of plant communities. Princeton University Press

Tripathi SN, Raghubanshi AS (2014) Seedling growth of five tropical dry forest tree species in relation to light and nitrogen gradients. J Plant Ecol 7:250-263. doi: 10.1093/jpe/rtt026 
Trollope WSW (1984) Fire in savanna. In: Booysen P d. V, Tainton NM (eds) Ecological effects of fire in South African ecosystems. Springer, pp 149-176

Vadigi S, Ward D (2013) Shade, nutrients, and grass competition are important for tree sapling establishment in a humid savanna. Ecosphere 4:art142. doi: 10.1890/ES13-00239.1

Vadigi S, Ward D (2014) Herbivory effects on saplings are influenced by nutrients and grass competition in a humid South African savanna. Perspect Plant Ecol Evol Syst 16:11-20. doi: 10.1016/j.ppees.2013.10.002

Vadigi S, Ward D (2012) Fire and nutrient gradient effects on the sapling ecology of four Acacia species in the presence of grass competition. Plant Ecol 213:1793-1802. doi: 10.1007/s11258-012-0134-1

Varma V, Catherin AM, Sankaran M (2018) Effects of increased N and P availability on biomass allocation and root carbohydrate reserves differ between $\mathrm{N}$-fixing and non-N-fixing savanna tree seedlings. Ecol Evol 8:8467-8476. doi: 10.1002/ece3.4289

Verma P, Sagar R, Verma H, Verma P, Singh DK (2014) Changes in species composition, diversity and biomass of herbaceous plant traits due to $\mathrm{N}$ amendment in a dry tropical environment of India. $\mathrm{J}$ Plant Ecol rtu018. doi: 10.1093/jpe/rtu018

Vesk PA, Westoby M (2004) Funding the bud bank: a review of the costs of buds. Oikos 106:200-208. doi: 10.1111/j.0030-1299.2004.13204.x

Vet R, Artz RS, Carou S, Shaw M, Ro C-U, Aas W, Baker A, Bowersox VC, Dentener F, Galy-Lacaux C, Hou A, Pienaar JJ, Gillett R, Forti MC, Gromov S, Hara H, Khodzher T, Mahowald NM, Nickovic S, Rao PSP, Reid NW (2014) A global assessment of precipitation chemistry and deposition of sulfur, nitrogen, sea salt, base cations, organic acids, acidity and $\mathrm{pH}$, and phosphorus. Atmos Environ 93:3-100. doi: 10.1016/j.atmosenv.2013.10.060

Vitousek PM (1994) Beyond global warming: ecology and global change. Ecology 75:1861-1876

Vitousek PM, Aber JD, Howarth RW, Likens GE, Matson PA, Schindler DW, Schlesinger WH, Tilman DG (1997) Human alteration of the global nitrogen cycle: sources and consequences. Ecol Appl 7:737750. doi: 10.1890/1051-0761(1997)007[0737:HAOTGN]2.0.CO;2

Vitousek PM, Cassman K, Cleveland C, Crews T, Field CB, Grimm NB, Howarth RW, Marino R, Martinelli L, Rastetter EB, Sprent JI (2002) Towards an ecological understanding of biological nitrogen fixation. Biogeochemistry 57-58:1-45. doi: 10.1023/A:1015798428743

Vitousek PM, Menge DNL, Reed SC, Cleveland CC (2013) Biological nitrogen fixation: rates, patterns and ecological controls in terrestrial ecosystems. Philos Trans R Soc B Biol Sci 368:20130119. doi: $10.1098 /$ rstb.2013.0119

Wakeling JL, Staver AC, Bond WJ (2011) Simply the best: the transition of savanna saplings to trees. Oikos 120:1448-1451. doi: 10.1111/j.1600-0706.2011.19957.x

Wang Y-L, Almvik M, Clarke N, Eich-Greatorex S, Øgaard AF, Krogstad T, Lambers H, Clarke JL (2015) Contrasting responses of root morphology and root-exuded organic acids to low phosphorus availability in three important food crops with divergent root traits. AoB Plants plv097. doi: 10.1093/aobpla/plv097

Wassen MJ, Venterink HO, Lapshina ED, Tanneberger F (2005) Endangered plants persist under phosphorus limitation. Nature 437:547-550. doi: 10.1038/nature03950 
Wigley BJ, Cramer MD, Bond WJ (2009) Sapling survival in a frequently burnt savanna: mobilisation of carbon reserves in Acacia karroo. Plant Ecol 203:1-11. doi: 10.1007/s11258-008-9495-x

Williams RJ, Cook GD, Gill AM, Moore PHR (1999) Fire regime, fire intensity and tree survival in a tropical savanna in northern Australia. Aust $J$ Ecol 24:50-59. doi: 10.1046/j.14429993.1999.00946.x

Wright IJ, Reich PB, Westoby M, Ackerly DD, Baruch Z, Bongers F, Cavender-Bares J, Chapin T, Cornelissen JHC, Diemer M, Flexas J, Garnier E, Groom PK, Gulias J, Hikosaka K, Lamont BB, Lee T, Lee W, Lusk C, Midgley JJ, Navas M-L, Niinemets Ü, Oleksyn J, Osada N, Poorter H, Poot P, Prior L, Pyankov VI, Roumet C, Thomas SC, Tjoelker MG, Veneklaas EJ, Villar R (2004) The worldwide leaf economics spectrum. Nature 428:821-827. doi: 10.1038/nature02403

Xia J, Wan S (2008) Global response patterns of terrestrial plant species to nitrogen addition. New Phytol 179:428-439. doi: 10.1111/j.1469-8137.2008.02488.x

Zavaleta ES, Shaw MR, Chiariello NR, Mooney HA, Field CB (2003) Additive effects of simulated climate changes, elevated $\mathrm{CO}_{2}$, and nitrogen deposition on grassland diversity. Proc Natl Acad Sci 100:7650-7654. doi: 10.1073/pnas.0932734100 